\title{
EFFECTS OF NITROGEN ON PRODUCTIVITY, GRAIN QUALITY, AND OPTIMAL NITROGEN RATES IN WINTER WHEAT CV. KUMPA-INIA IN ANDISOLS OF SOUTHERN CHILE
}

\author{
Ricardo Campillo $^{*}$, Claudio Jobet ${ }^{1}$, and Pablo Undurraga ${ }^{2}$
}

\begin{abstract}
Nitrogen is one of the main inputs of the winter wheat crop (Triticum aestivum L.) in southern Chile. Nitrogen efficient management is basic to optimizing its utilization while decreasing pollution risks and operational costs. Crop response and $\mathrm{N}$ use efficiency (NUE, defined as the ratio of yield to mineral $\mathrm{N}$ supply, regardless of source) are important for evaluating $\mathrm{N}$ requirements of winter wheat, and reaching maximum and economic yields. The objective of this study was to determine the effect of $\mathrm{N}$ rate on grain yield, calculate the $\mathrm{N}$ rate that maximizes yield, and estimate the optimal grain yield rate and quality of high-yielding winter wheat cv. Kumpa-INIA. Five annual N rates were evaluated in a randomized complete block design during two successive winter wheat cropping seasons on a Vilcún series soil of the Pachic Melanudands family (Andisol) in La Araucania Region, Chile, and subjected to intensive annual crop rotation. Significant effects $(\mathrm{P} \leq 0.01)$ of $\mathrm{N}$ rate on grain yield and quality were found. The optimal physical $\mathrm{N}$ rate (OPR) in both seasons ranged from 290 to $339 \mathrm{~kg} \mathrm{ha}^{-1}$, whereas optimal economic $\mathrm{N}$ rate (OER) ranged from 248 to $274 \mathrm{~kg} \mathrm{ha}^{-1}$, with yields between 10.2 and $10.1 \mathrm{t} \mathrm{ha}^{-1}$. Nitrogen use efficiency associated

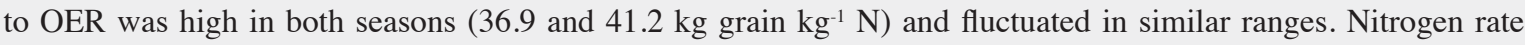
increased hectoliter weight and grain protein, but decreased NUE.
\end{abstract}

Key words: nitrogen level, nitrogen use efficiency, Andisols, Triticum aestivum.

\section{INTRODUCTION}

Wheat productivity and quality in southern Chile is conditioned by diverse factors of which climate, genetics, and crop management are the most relevant. Chilean wheat productivity is the highest in the Southern Cone and is sustained by the use of high-yield potential varieties that require, among other things, an intensive use of inputs such as fertilizers (Fundación Chile, 2005).

High yields are the result of environmental, technological, management, capital, and input conditions. High wheat yields require increases in $\mathrm{N}$ application and the excessive addition of this nutrient can contribute to watercourse pollution (Semenov et al., 2007). Therefore, the use of high $\mathrm{N}$ rates that allow expressing yield potential of existing varieties in the actual market require careful and efficient management of nutrient partialization with the purpose of minimizing losses due to lixiviation during crop development, avoiding pollution of the underground

'Instituto de Investigaciones Agropecuarias INIA, Casilla 58-D, Temuco, Chile. "Corresponding author (rcampill@inia.cl).

${ }^{2}$ Instituto de Investigaciones Agropecuarias INIA, Casilla 426, Chillán, Chile.

Received: 30 January 2009.

Accepted: 30 June 2009 water tables and its harmful effect on human health and environmental sustainability.

It is actually estimated that global grain demand will be duplicated by the year 2050 (Cassmann, 1999; Tilman et al., 2002). Cereal producers are under pressure to increase their yields and maintain their profitability despite a group of environmental restrictions and high fertilizer costs (Semenov et al., 2007). Compared to other Southern Cone countries, Chile presents high input costs for fertilizers and pesticides, costs which are one of the factors affecting total production cost the most (Fundación Chile, 2005). In general, the international price of fertilizers, as for many other products, has been rising in the recent past. However, the increase experienced by fertilizers is significantly greater than that recorded for other products such as wood, grains, food, and energy (ODEPA, 2008a).

Fertilizers represented $30 \%$ of direct crop costs in Chile (Fundación Chile, 2005) in a mean yield situation ( 5 to $6 \mathrm{t} \mathrm{ha}^{-1}$ ), increasing to $36 \%$ in high-yield management (over $8 \mathrm{t} \mathrm{ha}^{-1}$ ). However, during 2008, this direct cost has escalated to $47 \%$ as a result of the high price increase in input and raw materials, such as oil and natural gas that are so important for the production of ammonium $\mathrm{N}$ fertilizers (ODEPA, 2008a). Although fertilizer prices have returned to their original prices during 2009 as a 
consequence of the severe international economic crisis, it is quite probable that the phenomenon will occur again in the medium-term given its dependence on the price of fossil fuels and its condition of non-renewable resource. Among the fertilizer inputs used in wheat crops, $\mathrm{N}$ fertilizer normally affects production costs more than other inputs (Fundación Chile, 2005).

Greater knowledge about the factors that determine the rational use of $\mathrm{N}$ allows producers to be more efficient from the technical as well as economic point of view in the use of fertilizers through adequate agronomic and environmental practices (Parodi, 2003). Production of high wheat yields requires the application of high $\mathrm{N}$ rates, and the excess of this nutrient can promote watercourse pollution. This constitutes an incentive to maximize $\mathrm{N}$ use efficiency (NUE) in productive systems.

Moll et al. (1982) defined NUE as grain production per unit of available $\mathrm{N}$ in the soil. These authors indicated that available $\mathrm{N}$ in the soil and total $\mathrm{N}$ in the plant are difficult to measure adequately. They proposed substituting these measurements for $\mathrm{N}$ fertilizer and $\mathrm{N}$ from the aerial part of the plant, respectively. In addition, they established that NUE can be divided in the components of $\mathrm{N}$ uptake efficiency ( $\mathrm{N}$ in the plant per unit of $\mathrm{N}$ fertilizer), and $\mathrm{N}$ utilization efficiency (grain yield per unit of $\mathrm{N}$ in the plant). The product of these two components is expressed as NUE (Moll et al., 1982; Ortiz-Monasterio et al., 1997; Dawson et al., 2008).

A similar approximation was stated by Semenov et al. (2007) who defined NUE as the ratio between yield and input of $\mathrm{N}$ mineral regardless of source: $\mathrm{NUE}=\mathrm{Y} \mathrm{N}_{\mathrm{s}}{ }^{-1}$, where $\mathrm{N}_{\mathrm{s}}\left(\mathrm{kg} \mathrm{ha}^{-1}\right)$ is available $\mathrm{N}$ for the plant during the growth period, including initial inorganic $\mathrm{N}$ in the soil, applied $\mathrm{N}$ fertilizer, and mineralized $\mathrm{N}$ from organic $\mathrm{N}$ during the growth period, and $\mathrm{Y}$ is grain yield $\left(\mathrm{kg} \mathrm{ha}^{-1}\right)$. The atmospheric contribution of $\mathrm{N}$ was not considered because it represents a negligible source in relation to the others (Cassman et al., 1998). In this case, for both $\mathrm{N}$ efficiency and absorption from the soil $\mathrm{N}_{\text {crop }} \mathrm{N}_{\mathrm{s}}{ }^{-1}$ and $\mathrm{N}$ conversion into grain yield $\mathrm{Y} \mathrm{N}_{\text {crop }}{ }^{-1}$ can be expressed as $\mathrm{Y} \mathrm{N}_{\mathrm{s}}^{-1}=\left(\mathrm{N}_{\text {crop }} \mathrm{N}_{\mathrm{s}}^{-1}\right)\left(\mathrm{Y} \mathrm{N}_{\text {crop }}{ }^{-1}\right)$.

There are also alternative definitions of NUE in the literature (Cassman et al., 1998; Tilman et al., 2002; Raun et al., 2002) and it is known that there are substantial discrepancies on how NUE should be defined. The objective of this study is not to thoroughly analyze this topic. Given that we are interested in considering the productive value of $\mathrm{N}$, the definition of NUE adopted in this article is the ratio of yield related to $\mathrm{N}$ mineral input regardless of source (Moll et al., 1982; Semenov et al., 2007).

Obtaining high NUE is very important in actual crop production. Nitrogen use efficiency can be increased through the selection of crop growth environment (soil type and climate), management practices (sowing date, rate, and partialization of $\mathrm{N}$ application), and crop breeding (Semenov et al., 2007).

Nitrogen use efficiency in cereals (calculated as $\mathrm{NUE}=($ total cereal $\mathrm{N}$ removed $-(\mathrm{N}$ soil $+\mathrm{N}$ rain $)) / \mathrm{N}$ cereal fertilizer) is actually estimated at 33\% (Raun and Johnson, 1999), a figure quite lower than the 50\% normally reported in the literature (Rodríguez, 1991). Various ${ }^{15} \mathrm{~N}$ recovery experiments have reported losses of 20 to $50 \%$ of $\mathrm{N}$ fertilizer in wheat, attributed to the combined effects of denitrification, volatilization, and lixiviation (Raun and Johnson, 1999; Urquiaga, 2000). Field experiments in Central Europe have recorded, on the average, 50 to $60 \%$ recovery of $\mathrm{N}$ fertilizer applied to winter wheat (grain and chaff) (Blankenau et al., 2002; Macdonald et al., 2002).

Modifying the timing and the application method of $\mathrm{N}$ can also lead to an improvement in absorption efficiency. One of the main causes of low NUE in actual $\mathrm{N}$ management practices is the scarce synchrony between $\mathrm{N}$ soil input and crop demand (Raun and Johnson, 1999; Cassmann et al., 2002; Fageria and Baligar, 2005).

Producers are sowing a wide range of new wheat cultivars in southern Chile which require high annual rates of $\mathrm{N}$ to describe their productivity. La Araucanía Region presents a large area of annual crops in which wheat dominates. During the 2006-2007 season, this region had a planted area of 230070 ha of annual crops of which 107800 ha were wheat with a mean yield of $4.60 \mathrm{t} \mathrm{ha}^{-1}$ (ODEPA, 2008b).

Winter wheat 'Kumpa-INIA' is characterized by its high yield potential in the southern zone of Chile, normally reaching the maximum grain yields among the different winter cultivars on the market with productivity over 11 $\mathrm{t} \mathrm{ha}^{-1}$ in areas of more than 200 ha sown. Its agronomic type, reed firmness, high number of ears, and leaf color has allowed it to become a variety that is suitable for the demanding conditions of southern Chile. 'KumpaINIA' was officially released in 2002 for the National Wheat Program of the Instituto de Investigaciones Agropecuarias (INIA), Temuco, and available to regional agriculture in the 2003 season. Results have given it a high yield potential for an important area which covers localities from the Bío Bío Region to Los Lagos Region with acceptable quality and sanitation. Height of the adult plant varies between 85 and $100 \mathrm{~cm}$ with a mean of 95 $\mathrm{cm}$, a stem resistant to lodging which allows it to adapt to the conditions in southern Chile (Jobet and Hewstone, 2003). The vegetative period from sowing to ear formation in Temuco (La Araucanía Region) is about 182 to $184 \mathrm{~d}$, approximately $189 \mathrm{~d}$ in Purranque (Los Lagos Region), and is actually one of the most recommended late varieties. Its quality, measured by its humid gluten, 
sedimentation, protein content, and alveogram (Jobet and Hewstone, 2003) locates it in the intermediate wheat category in accordance with the Chilean Norm (Instituto Nacional de Normalización, 2000).

The objective of this study was to determine the effect of $\mathrm{N}$ on wheat grain production, hectoliter weight, and grain quality, as well as estimating rates that optimize productivity in a high-yield wheat cultivar such as KumpaINIA in an Andisol in the La Araucanía Region subjected to more than $20 \mathrm{yr}$ of intensive annual crop rotation.

\section{MATERIALS AND METHODS}

The study was carried out on the property of a cereal producer in the commune of Vilcún ( $38^{\circ} 41^{\prime} \mathrm{S}, 72^{\circ} 25^{\prime} \mathrm{W}$, 200 m.a.s.1.), La Araucanía Region, Chile, during two consecutive seasons (2004-2005 and 2005-2006). The soil corresponded to a Vilcún series, member of the medial, isomesic of the Pachic Melanudand (Andisol) family (CIREN, 2002). This soil was subjected to an intensive annual crop rotation under the no-till system with burning of harvesting residues. The initial characterization of the soils was carried out in accordance with methodologies established in Sadzawka et al. (2006) (Table 1). The chemical analyses of both sites were carried out in the INIA Soil Analysis Laboratory. Both sites corresponded to different fields of the same property, presented adequate fertility levels with moderate acidity limitations, and a low initial $\mathrm{N}$ level.

The randomized complete block experimental design was used with four replicates in $10 \mathrm{~m}^{2}(2 \times 5 \mathrm{~m})$ plots. Five treatments were evaluated consistent with annual rates of $\mathrm{N}: 0,150,200,250$, and $300 \mathrm{~kg} \mathrm{ha}^{-1}$ with the commercial $\mathrm{N}$ fertilizer $(\mathrm{CNF})$ urea $(46 \% \mathrm{~N})$. In the treatments that considered annual rates of $\mathrm{N}$, initial fertilization with calcium ammonium nitrate $\left(40 \mathrm{~kg} \mathrm{ha}^{-1} \mathrm{~N}\right)$ was deducted.

The soil received lime neutralization 1 mo before sowing equivalent to $3 \mathrm{t} \mathrm{ha}^{-1}$ (May 2004) and $1 \mathrm{t} \mathrm{ha}^{-1}$ (May 2005) of pure $\mathrm{CaCO}_{3}$ (Soprocal calcium correction, equivalent to $90 \%$ calcium carbonate) to prevent damage from the acidifying effect of CNF (Campillo and Sadzawka, 2006). Total CNF rate was partialized in four applications, the corresponding decimal code is indicated between parentheses for the cereal growth stages according to Zadoks et al. (1974): at sowing $\left(Z_{0}\right)$; two tillers $\left(Z_{22}\right)$; end of tillering $\left(Z_{30}\right)$, and two nodes $\left(\mathrm{Z}_{32}\right)$. In the sowing furrow, $40 \mathrm{~kg} \mathrm{ha}^{-1} \mathrm{~N}$ was applied as calcium ammonium nitrate $(27-0-0-5 \% \mathrm{MgO}-7 \% \mathrm{CaO})$. The rest of each evaluated $\mathrm{N}$ rate was applied as $\mathrm{CNF}$ and partialized in the $Z_{22}, Z_{30}$, and $Z_{32}$ stages in the following way: $\mathrm{N}_{150}(50+60+0) ; \mathrm{N}_{200}(80+40+40) ; \mathrm{N}_{250}(80+90+40)$, and $\mathrm{N}_{300}(80+140+40)$.

In both years, sowing was done with an assay rototiller (Planet Junior, Allen Co, New Jersey, USA). Soil samples were collected for chemical characterization before sowing and just after harvest. Sowing dates were 17 June 2004 and 22 June 2005. Wheat sown was cv. Kumpa-INIA (winter wheat) with oat (Avena sativa $\mathrm{L}$.) as the previous crop. Seed rate was $200 \mathrm{~kg} \mathrm{ha}^{-1}$, disinfected with $200 \mathrm{~g} \mathrm{~L}^{-1}$ doses of triticonazole (Real 200 SC, BASF).

A fertilization base was established for the crop to compensate any nutritional limitation that is not $\mathrm{N}$.

Table 1. Chemical characterization of soil $(0-20 \mathrm{~cm})$ before establishing experiments. 2004-2005 and 2005-2006 seasons.

\begin{tabular}{|c|c|c|}
\hline Chemical characteristics & $\begin{array}{c}\text { Season } \\
2004-2005\end{array}$ & $\begin{array}{c}\text { Season } \\
2005-2006\end{array}$ \\
\hline P Olsen, $\mathrm{mg} \mathrm{kg}^{-1}$ & 24.00 & 20.00 \\
\hline Organic matter, $\%$ & 18.00 & 17.60 \\
\hline Inorganic $\mathrm{N}, \mathrm{mg} \mathrm{kg}^{-1}$ & 25.00 & 22.00 \\
\hline Water $\mathrm{pH}, 1: 2.5$ & 5.56 & 5.72 \\
\hline Exchangeable $\mathrm{Ca}, \mathrm{cmol}_{+} \mathrm{kg}^{-1}$ & 2.42 & 2.09 \\
\hline Exchangeable $\mathrm{Mg}, \mathrm{cmol}_{+} \mathrm{kg}^{-1}$ & 0.48 & 0.52 \\
\hline Exchangeable $\mathrm{Na}, \mathrm{cmol}_{+} \mathrm{kg}^{-1}$ & 0.14 & 0.05 \\
\hline Exchangeable $\mathrm{K}, \mathrm{cmol}_{+} \mathrm{kg}^{-1}$ & 0.60 & 0.59 \\
\hline Sum of exchangeable bases, $\mathrm{cmol}_{+} \mathrm{kg}^{-1}$ & 3.64 & 3.25 \\
\hline Exchangeable $\mathrm{Al}, \mathrm{cmol}_{+} \mathrm{kg}^{-1}$ & 0.38 & 0.11 \\
\hline $\mathrm{ECEC}, \mathrm{cmol}_{+} \mathrm{kg}^{-1}$ & 4.02 & 3.35 \\
\hline $\mathrm{Al}$ saturation, $\%$ & 9.50 & 3.42 \\
\hline $\mathrm{Zn}, \mathrm{mg} \mathrm{kg}^{-1}$ & 0.78 & 0.73 \\
\hline $\mathrm{B}, \mathrm{mg} \mathrm{kg}^{-1}$ & 0.98 & 0.39 \\
\hline $\mathrm{S}, \mathrm{mg} \mathrm{kg}^{-1}$ & 21.20 & 33.60 \\
\hline
\end{tabular}

ECEC: effective cation exchange capacity. 
A fertilization base was applied (per ha) in the sowing furrow consisting of $150 \mathrm{~kg} \mathrm{P}_{2} \mathrm{O}_{5}$ (triple superphosphate), $55 \mathrm{~kg} \mathrm{~K}{ }_{2} \mathrm{O}, 55 \mathrm{~kg} \mathrm{~S}, 45 \mathrm{~kg} \mathrm{MgO}$ (sulpomag), $2.5 \mathrm{~kg} \mathrm{~B}$ (boronatrocalcite), and $2.2 \mathrm{~kg} \mathrm{Zn} \mathrm{(zinc} \mathrm{sulfate).} \mathrm{This}$ sowing fertilization was complemented with a random cover application of $50 \mathrm{~kg} \mathrm{~K}_{2} \mathrm{O}$ and $18 \mathrm{~kg} \mathrm{~S}$ (potassium sulfate).

The chemical control of weeds in both seasons was carried out in postharvest with prosulfocarb (AFIPA, 2006) in $4 \mathrm{~L} \mathrm{ha}^{-1}$ rates (Falcon, SYNGENTA) for the control of preemergent gramineae. The full tiller stage $\left(\mathrm{Z}_{26}\right)$ was complemented with iodosulfuron-methylsodium in $50 \mathrm{~g} \mathrm{~kg}^{-1}$ rates (Hussar $20 \mathrm{WG}$, BAYER) to control gramineae and broad leaf.

In the phenological stage $Z_{30}$ of the 2004-2005 season, prochloraz + carbendazim fungicides were used in rates of $300 \mathrm{~g} \mathrm{~L}^{-1}+80 \mathrm{~g} \mathrm{~L}^{-1}$ (Sportak $40 \mathrm{EC}$, ANASAC CHILE) and benomyl in rates of $500 \mathrm{~g} \mathrm{~kg}^{-1}$ (Benlate, ARYSTA LIFESCIENCE). This same application was repeated for the $Z_{32}$ and $Z_{39}$ stages to prevent the presence of leaf diseases. Foliar diseases in the 2005-2006 season were controlled in a similar way with prochloraz and benomyl fungicides. The phytoregulator chlormequat chloride + choline chloride was used in both seasons in the $\mathrm{Z}_{28}$ stage with $460 \mathrm{~g} \mathrm{~L}^{-1}+320 \mathrm{~g} \mathrm{~L}^{-1}$ rates (Cycocel extra, BASF).

During the summer crop growth period, soil samples were collected (depths of 0-20 and 20-40 cm) to determine the evolution of the gravimetric humidity content (dry weight base) in the root zone (Campillo et al., 2007). Experiments were harvested on 15 February 2005 and 20 February 2006. Grain yield was determined with $14 \%$ dry weight humidity base (DWHB), hectoliter weight, and grain $\mathrm{N}$ by the combustion method with a macro elemental analyzer (Vario MAX CNS, Elementar, Germany, 2001; Bremmer and Mulvaney, 1982). Protein content was obtained with a conversion factor $(\% \mathrm{~N} x$ 5.7). Grain yield data, hectoliter weight, and grain protein were subjected to ANOVA and treatment means to Tukey test $(\mathrm{P} \leq 0.05)$ when applicable (SAS Institute, 1990).

It was possible to establish the optimal physical rates (OPR) of $\mathrm{N}$ derived from the experiment and its corresponding maximum grain production yield by adjusting a second degree polynomial to the grain yield results of 'Kumpa-INIA' wheat (Volke, 1982; Rebolledo, 1999; Campillo et al., 2007). Fertilizer N cost (FNC) and a value per ton of wheat was assumed in order to calculate the relationship of input prices/product and estimate the optimal economic rates (OER) of $\mathrm{N}$ and its respective grain production optimal economic yield. The unlimited capital economic criterion was used with the restriction of a 50\% minimum rate of return (Volke, 1982).

\section{RESULTS AND DISCUSSION}

In general, the year 2004 showed abundant precipitation (1559 $\mathrm{mm})$ through spring, thus ensuring a good water supply (525 mm from September to February) for wheat crop development. There were no important humidity restrictions in both soil strata $(0-20$ and $20-40 \mathrm{~cm})$, maintaining content over $50 \%$ usable humidity during most of crop development (data not shown). Climatic information during the 2005-2006 season (1892 mm) showed a similar situation with abundant precipitation during most of the year $(568 \mathrm{~mm}$ for September to February) ensuring an adequate water supply for all crops in the zone. As a result, during 2005 soil water content was maintained close to field capacity during most of the crop development period. This background information allows stating that the wheat crop was not affected by hydric stress, thus ensuring normal grain filling.

Grain production of cv. Kumpa-INIA in both seasons increased $(\mathrm{P}<0.01)$ with $\mathrm{N}$ rates, showing a low coefficient of variation (4.7 to 5.1\%). Grain yield for the two seasons (Tables 2 and 3) was between 3.85 (control

Table 2. Effect of $N$ rate on grain yield and $N$ use efficiency (NUE) of wheat cv. Kumpa-INIA, 2004-2005 season.

\begin{tabular}{|c|c|c|c|}
\hline Annual N & Grain yield & Quadratic adjustments & NUE \\
\hline $\mathrm{kg} \mathrm{ha}^{-1}$ & 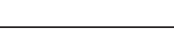 & $\mathrm{ha}^{-1}$ & $\mathrm{~kg}_{\text {grain }} \mathrm{kg}^{-1} \mathrm{Ns}$ \\
\hline 0 & $3.85 \mathrm{c}$ & 3.86 & \\
\hline 150 & $8.84 b$ & 8.84 & 58.9 \\
\hline 200 & $9.84 \mathrm{ab}$ & 9.73 & 48.7 \\
\hline 250 & $10.06 \mathrm{a}$ & 10.23 & 40.9 \\
\hline 300 & $10.42 \mathrm{a}$ & 10.34 & 34.5 \\
\hline $\mathrm{CV}, \%$ & 4.7 & & \\
\hline Significance of $F$ test & & & \\
\hline
\end{tabular}

Means with different letters indicate significant differences according to Tukey test $(\mathrm{P}<0.05)$.

Ns: $\mathrm{N}$ supplied by soil and fertilizer.

$\mathrm{CV}$ : coefficient of variation; **: $\mathrm{P}<0.01$. 
Table 3. Effect of $\mathrm{N}$ rate on grain yield and $\mathrm{N}$ use efficiency (NUE) of wheat cv. Kumpa-INIA, 2005-2006 season.

\begin{tabular}{|c|c|c|c|}
\hline Annual N & Grain yield & Quadratic adjustments & NUE \\
\hline $\mathrm{kg} \mathrm{ha}^{-1}$ & 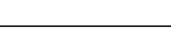 & $\mathrm{t} \mathrm{ha}^{-1}$ & $\mathrm{~kg}$ grain $\mathrm{kg}^{-1} \mathrm{Ns}$ \\
\hline 0 & $4.46 \mathrm{~d}$ & 4.46 & \\
\hline 150 & $8.52 \mathrm{c}$ & 8.52 & 56.8 \\
\hline 200 & $9.36 \mathrm{bc}$ & 9.35 & 46.8 \\
\hline 250 & $9.93 \mathrm{ab}$ & 9.94 & 39.8 \\
\hline 300 & $10.27 \mathrm{a}$ & 10.27 & 34.2 \\
\hline $\mathrm{CV}, \%$ & 5.10 & & \\
\hline Significance of $F$ test & & $* *$ & \\
\hline
\end{tabular}

Means with different letters indicate significant differences according to Tukey test $(\mathrm{P}<0.05)$.

Ns: N supplied by soil and fertilizer.

$\mathrm{CV}$ : coefficient of variation; **: $\mathrm{P}<0.01$.

without $\mathrm{N})$ and $10.42 \mathrm{t} \mathrm{ha}^{-1}\left(300 \mathrm{~kg} \mathrm{ha}^{-1} \mathrm{~N}\right)$. The most efficient production in both cases was associated with the highest annual $\mathrm{N}$ applications.

This study defined NUE as grain production per unit of $\mathrm{N}$ supplied (i.e. available $\mathrm{N}$ for the plant during the growth period, including initial inorganic $\mathrm{N}$ in the soil, applied $\mathrm{N}$ fertilizer, and mineralized $\mathrm{N}$ from organic $\mathrm{N}$ during this period) (Moll et al., 1982; Ortiz-Monasterio et al., 1997; Semenov et al., 2007). This NUE decreased in both seasons (Tables 2 and 3 ) as a function of the increase of the annual applied rate.

Nitrogen use efficiencies calculated for cv. KumpaINIA were high and relatively stable in both seasons, fluctuating between 58.9 and 34.5 (2004-2005) and between 56.8 and 34.2 (2005-2006). The $250 \mathrm{~kg} \mathrm{ha}^{-1} \mathrm{~N}$ rate had a high productive and economic efficiency since it was associated with the optimal economic rates estimated from the quadratic model (Tables 2 and 3).

Nitrogen use efficiencies calculated for cv. KumpaINIA were higher than the values normally pointed out in other research studies. López-Bellido et al. (2006) found that wheat NUE fluctuated between 19.2 and 20.6 with $150 \mathrm{~kg} \mathrm{ha}^{-1}$ during a 3-yr period when comparing different partializations of $\mathrm{N}$ in a Vertisol characteristic of the Mediterranean region in Andalucía, Spain. Díaz et al. (2002) found that NUE was lower than $6 \mathrm{~kg}$ grain $\mathrm{kg}^{-1} \mathrm{~N}$ applied with a rate of $240 \mathrm{~kg} \mathrm{ha}^{-1}$ in annual sowing of winter wheat in Andisols of the foothills of the Bío Bío Region, Chile. However, Mellado (1992), who partialized the $\mathrm{N}$ rate in an Andisol in the Province of Nuble, Chile, determined that a $150 \mathrm{~kg} \mathrm{ha}^{-1} \mathrm{~N}$ application achieved the highest NUE in the tiller stage of winter wheat, varying between 22 and 30 over a 4-yr period. Ortiz-Monasterio et al. (1997) compared NUE of 10 wheat cultivars produced by CIMMYT (Centro Internacional de Mejoramiento del Maíz y Trigo) in Sonora, Mexico, and found that the mean NUE was $35 \mathrm{~kg}$ grain $\mathrm{kg}^{-1} \mathrm{~N}$ with a rate of $150 \mathrm{~kg} \mathrm{ha}^{-1} \mathrm{~N}$ and $18 \mathrm{~kg}$ grain $\mathrm{kg}^{-1} \mathrm{~N}$ with $300 \mathrm{~kg} \mathrm{ha}^{-1} \mathrm{~N}$.
It has been established that the application of $\mathrm{N}$ fertilizer can increase both the yield and the protein content of the grain (Fowler et al., 1990). Nitrogen use efficiency is greater when the yield response to $\mathrm{N}$ is high. Therefore, this efficiency is generally high with low $\mathrm{N}$ rates and decreases in accordance with the rate increase of applied N (Campbell et al., 1977; Clarke et al., 1990; Gauer et al., 1992; Parodi, 2003).

For the optimization process and calculation of $\mathrm{N}$ rates, both physical and economic, a second degree polynomial was adjusted to the grain yield results of cv. Kumpa-INIA obtained in both productive cycles. In this way, it was possible to estimate the optimal physical rate (OPR) of wheat production and its corresponding maximum yield (Figures 1 and 2).

The relationship of input prices/product was calculated from the fertilizer $\mathrm{N}$ cost (FNC) and the value per ton of wheat, and it was possible to determine the optimal economic rate (OER) of $\mathrm{N}$ for wheat production and its respective optimal economic yield. The unlimited capital economic criterion was used with the restriction of a $50 \%$ minimum rate of return (Volke, 1982; Rebolledo, 1999).

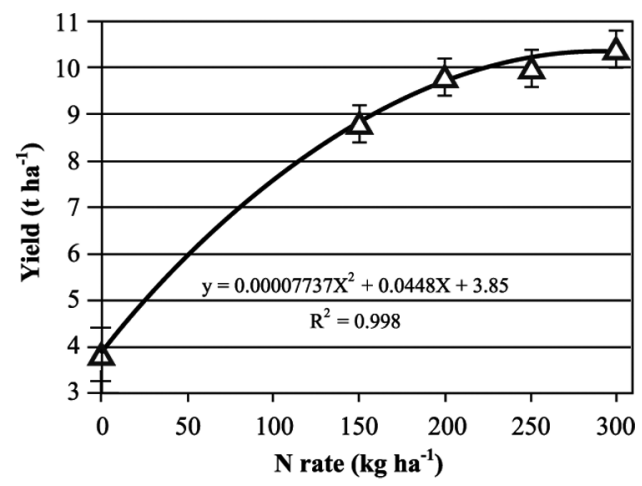

Vertical bars represent mean standard error.

Figure 1. Increase of wheat yield according to annual $\mathbf{N}$ rate. 2004-2005 season. 


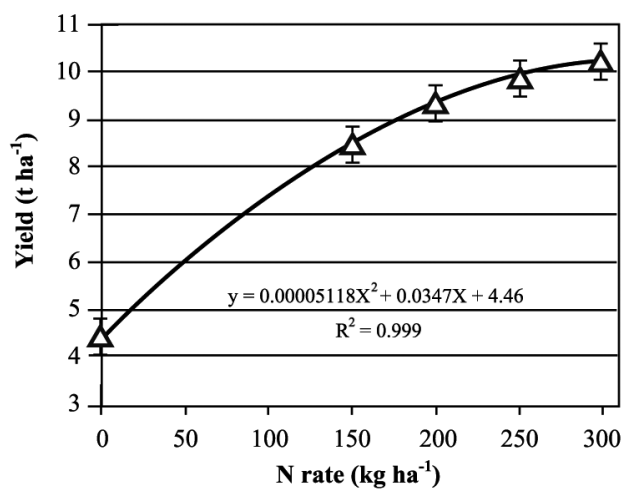

Vertical bars represent mean standard error.

Figure 2. Increase of wheat yield according to annual $\mathbf{N}$ rate, 2005-2006 season.

During the 2004-2005 season (Table 4), OPR reached $290 \mathrm{~kg} \mathrm{ha}^{-1}$, OER $248 \mathrm{~kg} \mathrm{ha}^{-1}$, and optimal yield of 10.22 $\mathrm{t} \mathrm{ha}^{-1}$. In the second season (2005-2006), optimal yield for 'Kumpa-INIA' was similar to the above-mentioned (10.13 t ha-1), but both estimated OPR (339 $\left.\mathrm{kg} \mathrm{ha}^{-1}\right)$ and OER (274 $\mathrm{kg} \mathrm{ha}^{-1}$ ) required for optimal yield showed an increase. That is, to obtain a similar grain yield, a smaller quantity o $\mathrm{N}$ applied to the crop was required during the 2004-2205 season in relation to the requirements of the following season. This production and optimized rates concur with NUE calculated for cv. Kumpa-INIA during the first year (Table 2), which were more efficient in productive and economic terms than those obtained in the second season (Table 3). Similar OER values of N and NUE of this Andisol Vilcún have been reported with sowings of alternative-habit wheat (Campillo et al., 2007).
It is important to remember that CNF applied in the Andisols was quickly enzymatically hydrolyzed in 1 or 2 d (Campillo and Rodríguez, 1984). Subsequently, its behavior in the soil is similar to any other form of ammonium N (Campillo and Rodríguez, 1984; Rodríguez, 1991), so that in 2 or $3 \mathrm{wk}$ both calcium ammonium nitrate (applied to the sowing furrow) and CNF experience similar transformations in the nitrification process.

Soil analysis carried out at harvest of the wheat crop of the 2004-2005 season (Table 5), showed that soil acidity (water $\mathrm{pH}$, exchangeable $\mathrm{Ca}$, exchangeable $\mathrm{Al}$, and $\mathrm{Al}$ saturation) were maintained without any significant changes because of the effect of the annual $\mathrm{N}$ rates applied as CNF.

This means that despite the known acidifying effect of CNF used, no adverse changes were apparent in the soil acidity parameters due to the corrective effect of lime neutralization that was applied in cereal pre-sowing. Similar results have been reported for this Andisol in alternative-habit wheat sowings with a high yield potential (Campillo et al., 2007). Lime neutralization is recommended when acidifying reaction fertilizers are applied in soils that did not initially show limitations due to acidification. This practice makes the use of acidic reaction fertilizers possible, such as CNF, neutralizing them with moderate applications of calcium carbonate (pre-sowing) to prevent eventual damage in crop development and production (Rodríguez, 1991; Suárez, 1994; Campillo and Sadzawka, 2006).

The increase in the level of applied $\mathrm{N}$ also increased hectoliter weight of the wheat grain (Table 6). In the first season, the $250 \mathrm{~kg} \mathrm{ha}^{-1} \mathrm{~N}$ rate obtained 82.5 while the 300

Table 4. Optimization of $\mathrm{N}$ rates in wheat cv. Kumpa-INIA, 2004-2005 and 2005-2006 seasons.

\begin{tabular}{lcccccc}
\hline Season & $\begin{array}{c}\mathbf{N} \\
\text { unit }\end{array}$ & $\begin{array}{c}\text { Wheat } \\
\text { price }\end{array}$ & OPR of N & $\begin{array}{c}\text { Maximum } \\
\text { yield }\end{array}$ & OER of $\mathbf{N}$ & $\begin{array}{c}\text { Optimal } \\
\text { yield }\end{array}$ \\
\hline & CLP $\$$ & $\$ \mathrm{t}^{-1}$ & $\mathrm{~kg} \mathrm{ha}^{-1}$ & $\mathrm{tha}^{-1}$ & $\mathrm{~kg} \mathrm{ha}^{-1}$ & $\mathrm{tha}^{-1}$ \\
$2004-2005$ & $433^{1}$ & 100000 & 290 & 10.36 & 248 & 10.22 \\
$2005-2006$ & $440^{2}$ & 100000 & 339 & 10.34 & 274 & 10.13 \\
\hline
\end{tabular}

${ }^{1}$ Commercial values April 2005. CLP \$: Chilean pesos (1 US\$ = CLP \$580).

${ }^{2}$ Commercial values April 2006. CLP \$: Chilean pesos (1 US\$ = CLP \$517).

Table 5. Effect of $\mathrm{N}$ rate on acidity parameters of Andisol Vilcún series at harvest of wheat cv. Kumpa-INIA. March 2005.

\begin{tabular}{|c|c|c|c|c|}
\hline Annual N & Water pH & Ca exchange & Al exchange & Al saturation \\
\hline $\mathrm{kg} \mathrm{ha}^{-1}$ & & $\longrightarrow$ & $\mathrm{cmol}_{+} \mathrm{kg}^{-1}$ & $\%$ \\
\hline 0 & $5.61 \pm 0.09$ & $3.87 \pm 0.38$ & $0.26 \pm 0.035$ & $4.51 \pm 0.32$ \\
\hline 200 & $5.51 \pm 0.06$ & $3.67 \pm 0.36$ & $0.29 \pm 0.041$ & $4.82 \pm 0.27$ \\
\hline 250 & $5.54 \pm 0.05$ & $4.05 \pm 0.32$ & $0.25 \pm 0.029$ & $4.69 \pm 0.29$ \\
\hline 300 & $5.63 \pm 0.08$ & $4.11 \pm 0.34$ & $0.28 \pm 0.037$ & $4.71 \pm 0.22$ \\
\hline
\end{tabular}


$\mathrm{kg} \mathrm{ha}^{-1} \mathrm{~N}$ rate reached 83.1 with no differences between them $(\mathrm{P}>0.05)$. During the second season, the $250 \mathrm{~kg}$ ha $^{-1}$ annual $\mathrm{N}$ rate obtained 81.7 and was greater than $(\mathrm{P}$ $<0.05)$ the rest of the $\mathrm{N}$ rates. These results indicate that the best hectoliter weight was obtained with $250 \mathrm{~kg} \mathrm{ha}^{-1}$ annual $\mathrm{N}$. In both seasons, and in the whole range of $\mathrm{N}$ fertilizer rates assayed, grain hectoliter weight values were always higher than the normal values considered for $\mathrm{cv}$. Kumpa-INIA (Jobet and Hewstone, 2003), thus ratifying the good climatic conditions apparent during grain filling.

Wheat grain protein percentage is frequently used as the main measurement of grain quality. Nitrogen fertilizer is one the most used tools to influence grain yield and quality, a fact based en general knowledge that this nutrient can increase grain yield, grain protein percentage, or both (Stone and Savin, 1999). Maximum protein values were restricted to high $\mathrm{N}$ rates in both seasons. Protein value in the first season reached $11.29 \%$ (300 $\mathrm{kg} \mathrm{ha}^{-1} \mathrm{~N}$ rate) and was higher $(\mathrm{P}<0.05)$ than $10.32 \%\left(250 \mathrm{~kg} \mathrm{ha}^{-1} \mathrm{~N}\right.$ rate $)$. In the 2005-2006 season, protein values were $11.30 \%\left(300 \mathrm{~kg} \mathrm{ha}^{-1}\right.$ $\mathrm{N}$ rate $)$ and $11.89 \%\left(250 \mathrm{~kg} \mathrm{ha}^{-1} \mathrm{~N}\right.$ rate $)$ with no difference $(\mathrm{P}>0.05)$ between $\mathrm{N}$ rates (Table 7$)$. As for hectoliter weight, grain protein values obtained in this experiment were high and similar to levels reported as normal for cv. Kumpa-INIA (Jobet and Hewstone, 2003). These results coincide with evaluations of various spring wheat cultivars

Table 6. Effect of $\mathrm{N}$ rate on hectoliter weight of wheat grain cv. Kumpa-INIA, 2004-2005 and 2005-2006 seasons.

\begin{tabular}{|c|c|c|}
\hline Annual N & 2004-2005 & 2005-2006 \\
\hline $\mathrm{kg} \mathrm{ha}^{-1}$ & \multicolumn{2}{|c|}{$-\mathrm{kg} \mathrm{hL}^{-1}$} \\
\hline 0 & $81.5 b$ & $80.0 \mathrm{~b}$ \\
\hline 150 & $81.3 b$ & 80.9ab \\
\hline 200 & $81.5 b$ & $81.1 \mathrm{ab}$ \\
\hline 250 & $82.5 \mathrm{a}$ & $81.7 \mathrm{a}$ \\
\hline 300 & $83.1 \mathrm{a}$ & $80.9 \mathrm{ab}$ \\
\hline
\end{tabular}

Means with different letters indicate significant differences according to Tukey test $(\mathrm{P}<0.05)$.

Table 7. Effect of $\mathrm{N}$ rate on protein content of wheat grain cv. Kumpa-INIA, 2004-2005 and 2005-2006 seasons.

\begin{tabular}{|c|c|c|}
\hline Annual N & 2004-2005 & 2005-2006 \\
\hline $\mathrm{kg} \mathrm{ha}^{-1}$ & & \\
\hline 0 & $7.81 \mathrm{~d}$ & $8.19 \mathrm{~d}$ \\
\hline 150 & $9.34 \mathrm{c}$ & $9.62 c$ \\
\hline 200 & $10.20 \mathrm{bc}$ & $10.29 b$ \\
\hline 250 & $10.32 b$ & $11.89 \mathrm{a}$ \\
\hline 300 & $11.29 \mathrm{a}$ & $11.30 \mathrm{a}$ \\
\hline
\end{tabular}

Means with different letters indicate significant differences according to Tukey test $(\mathrm{P}<0.05)$. carried out in Manitoba, Canada, where the increase in the level of $\mathrm{N}$ increased protein and $\mathrm{N}$ absorption while decreasing NUE (Gauer et al., 1992). At the same time, a study carried out in Eastern Canada to establish OER of $\mathrm{N}$ with a spring wheat cultivar using the ${ }^{15} \mathrm{~N}$ methodology, Tran and Tremblay (2000) found that protein concentration in the wheat grain increased linearly with $\mathrm{N}$ rate.

\section{CONCLUSIONS}

Optimization of $\mathrm{N}$ fertilization of wheat cv. Kumpa-INIA in Andisols of the La Araucanía Region, Chile pointed out an OPR of $290 \mathrm{~kg} \mathrm{ha}^{-1}$, OER of $248 \mathrm{~kg} \mathrm{ha}^{-1}$, and optimal economic yield of 10.22 $\mathrm{t} \mathrm{ha}^{-1}$ in the 2004-2005 season. Optimal economic yield was similar $\left(10.13 \mathrm{t} \mathrm{ha}^{-1}\right)$ in the second season (2005-2006), but both OPR (339 kg ha-1) and OER $\left(274 \mathrm{~kg} \mathrm{ha}^{-1}\right)$ showed increases.

The increase of applied $\mathrm{N}$ continuously decreased NUEs ( $\mathrm{kg}$ of grain produced $\mathrm{kg}^{-1} \mathrm{~N}$ supplied) in both productive cycles. Nitrogen used efficiencies calculated for cv. Kumpa-INIA were high with a range variation from 58.9 to 34.5 (2004-2005), and 56.8 to 34.2 (20052006). Nitrogen used efficiencies associated with OERs of $\mathrm{N}$ were 41.2 and 36.9 in both seasons. These values suggest that $\mathrm{N}$ fertilizer management during the crop development cycle was adequate and efficient.

Wheat grain hectoliter weight during both seasons increased with the level of $\mathrm{N}$ applied. The highest hectoliter weight values (82.5 and 83.1) in the 2004-2005 season of cv. Kumpa-INIA were associated to annual N rates of 250 and $300 \mathrm{~kg} \mathrm{ha}^{-1}$ with no differences $(\mathrm{P}>0.05)$ between them. The annual $\mathrm{N}$ rate of $250 \mathrm{~kg} \mathrm{ha}^{-1}$ in the second season was 81.7 and was higher $(\mathrm{P}<0.05)$ than the other $\mathrm{N}$ rates. Hectoliter weight values in both productive cycles were high and greater than the values considered as normal for cv. Kumpa-INIA.

The increase in the level of applied $\mathrm{N}$ increased grain protein percentage in both seasons. Protein value in the first season reached $11.29 \%$ (300 $\mathrm{kg} \mathrm{ha}^{-1} \mathrm{~N}$ rate) and was higher $(\mathrm{P}<0.05)$ than $10.32 \%\left(250 \mathrm{~kg} \mathrm{ha}^{-1} \mathrm{~N}\right.$ rate). Protein values in the 2005-2006 season were $11.30 \%$ (300 $\mathrm{kg} \mathrm{ha}^{-1}$ $\mathrm{N}$ rate) and $11.89 \%$ (250 $\mathrm{kg} \mathrm{ha}^{-1} \mathrm{~N}$ rate) with no difference $(\mathrm{P}>0.05)$ between rates. Grain protein values obtained in this experiment were high and similar to levels indicated as adequate for cv. Kumpa-INIA.

Soil acidity parameters (water $\mathrm{pH}, \mathrm{Ca}$ and $\mathrm{Al}$ exchange, and Al saturation) measured in the 2004-2005 season wheat crop harvest were maintained with no significant changes attributable to annual $\mathrm{N}$ rates applied as $\mathrm{CNF}$ as a consequence of the corrective effect of lime neutralization applied in cereal pre-sowing.

In accordance with these results, in Andisols of the La Araucanía Region subjected to intensive annual crop 
rotations, the application of OER around $250 \mathrm{~kg} \mathrm{ha}^{-1}$ annual $\mathrm{N}$ in high-yield potential cultivars such as KumpaINIA supports yields over $10 \mathrm{t} \mathrm{ha}^{-1}$ grain, thus combining high productive, economic, and sustainable efficiency.

\section{ACKNOWLEDGEMENTS}

The authors thank Carlos Toro, high-level agricultural technician from INIA-Carillanca for his valuable collaboration in the establishment and management of the field experiments.

\section{RESUMEN}

Efecto del nitrógeno en productividad, calidad del grano y dosis óptimas de nitrógeno en trigo invernal cv. Kumpa-INIA en Andisoles del Sur de Chile. El N es uno de los principales insumos del cultivo de trigo (Triticum aestivum L.) en Chile. Su manejo eficiente optimiza las dosis, disminuye los riesgos de contaminación y los costos de producción. La respuesta del cultivo y eficiencia de uso de $\mathrm{N}$ (NUE, definida como la razón de rendimiento y suministro de $\mathrm{N}$ mineral, independientemente de la fuente) son importantes para evaluar los requerimientos de $\mathrm{N}$ y alcanzar rendimientos máximos y económicos. El objetivo de este estudio fue determinar el efecto del $\mathrm{N}$ en la producción y las dosis que optimizan la productividad y calidad de grano de trigo invernal cv. Kumpa-INIA. Durante 2 años sucesivos en campo, se estudió en un diseño de bloques completos al azar el efecto de cinco dosis de $\mathrm{N}$ en un suelo serie Vilcún de la familia de los Pachic Melanudands (Andisol) de la Región de La Araucanía, Chile, bajo rotaciones intensivas de cultivos anuales. El $\mathrm{N}$ tuvo un efecto en la productividad y calidad del grano cosechado ( $\mathrm{P} \leq 0,01)$. Las dosis óptimas físicas (OPR) de $\mathrm{N}$ en ambas temporadas alcanzaron entre 290 y $339 \mathrm{~kg} \mathrm{ha}^{-1}$, mientras que las dosis óptimas económicas (OER) de $\mathrm{N}$ fluctuaron entre 248 y $274 \mathrm{~kg} \mathrm{ha}^{-1}$, con rendimientos entre 10,2 y $10,1 \mathrm{t} \mathrm{ha}^{-1}$. Las NUE asociadas a las OER fueron altas en ambas temporadas $\left(36,9\right.$ y $41,2 \mathrm{~kg}$ grano $\left.\mathrm{kg}^{-1} \mathrm{~N}\right) \mathrm{y}$ fluctuaron en rangos similares. El incremento de $\mathrm{N}$ elevó el peso hectolitro y el contenido de proteína del grano ( $\mathrm{P}$ $\leq 0,05)$, mientras que disminuyó la NUE.

Palabras clave: dosis de nitrógeno, eficiencia de uso de nitrógeno, Andisoles, Triticum aestivum.

\section{LITERATURE CITED}

AFIPA. 2006. Manual fitosanitario 2006-2007. 1160 p. Asociación Nacional de Fabricantes e Importadores de Productos Fitosanitarios Agrícolas (AFIPA), Santiago, Chile.
Blankenau, K., H.W. Olfs, and H. Kuhlmann. 2002. Strategies to improve the use efficiency of mineral fertilizer nitrogen applied to winter wheat. J. Agron. Crop Sci. 188:146-154.

Bremmer, J.M., and C.S. Mulvaney. 1982. Nitrogen - Total. p. 595-624. In L. Page et al. (eds.) Methods of soil analysis. Part 2. Chemical and microbiological properties. $2^{\text {nd }}$ ed. Agronomy 9. American Society of Agronomy, Soil Science Society of American, Madison, Wisconsin, USA.

Campbell, C.A., D.R. Cameron, W. Nicholaichuk, and H.R. Davidson. 1977. Effect of fertilizer N and soil moisture on growth, $\mathrm{N}$ content, and moisture use by spring wheat. Can. J. Soil Sci. 57:289-310.

Campillo, R., C. Jobet, y P. Undurraga. 2007. Optimización de la fertilización nitrogenada para trigo de alto potencial de rendimiento en Andisoles de la Región de La Araucanía, Chile. Agric. Téc. (Chile) 67:281-291.

Campillo, R., y J. Rodríguez. 1984. Efecto acidificante de las transformaciones de la urea en dos Andisoles de la Región de Los Lagos. Agric. Téc. (Chile) 44:131-138.

Campillo, R., y A. Sadzawka. 2006. La acidificación de los suelos. Origen y mecanismos involucrados. p. 44-60. In R. Campillo (ed.) Manejo de los recursos naturales en el sistema de incentivos para la recuperación de suelos degradados de La Araucanía. Serie Actas No 38 . Instituto de Investigaciones Agropecuarias, Centro Regional de Investigación Carillanca, Temuco, Chile.

Cassman, K.G. 1999. Ecological intensification of cereal production systems: Yield potential, soil quality, and precision agriculture. Proc. Natl. Acad. Sci. USA 96:5952-5959.

Cassman, K.G., A. Dobermann, and D.T. Walters. 2002. Agroecosystems, nitrogen-use efficiency, and nitrogen management. Ambio 31:132-140

Cassman, K.G., S. Peng, D.C. Olk, J.K. Ladha, W. Reichardt, A. Dobermann, and U. Singh. 1998. Opportunities for increased nitrogen-use efficiency from improved resource management in irrigated rice systems. Field Crops Res. 56:7-39.

CIREN. 2002. Descripciones de suelos. Materiales y símbolos. Estudio Agrológico IX Región. Publicación CIREN N ${ }^{\circ}$ 122. 360 p. Centro de Información de Recursos Naturales (CIREN), Santiago, Chile.

Clarke, J.M., C.A.Campbell,H.W.Cutforth, R.M.DePauw, and G.E. Wilkleman. 1990. Nitrogen and phosphorus uptake, translocation, and utilization efficiency of wheat in relation to environment and cultivar yield and protein levels. Can. J. Plant Sci. 70:965-977.

Dawson, J.C., D.R. Huggins, and S.S. Jones. 2008. Review. Characterizing nitrogen use efficiency in natural and agricultural ecosystems to improve the performance of cereal crops in low-input and organic agricultural systems. Field Crops Res. 107:89-101. 
Díaz, B.K., R. Ortega, y J. Riquelme. 2002. Mejores prácticas de manejo para la fertilización en precordillera. p. 71-96. In B.K. Díaz (ed.) Mejores prácticas de manejo. Cultivos tradicionales de la zona Centro Sur de Chile. Boletín INIA N ${ }^{\circ} 75$. Instituto de Investigaciones Agropecuarias, Centro Regional de Investigación Quilamapu, Chillán, Chile.

Fageria, N.K., and V.C. Baligar. 2005. Enhancing nitrogen use efficiency in crop plants. Adv. Agron. 88:97-185.

Fowler, D.B., J. Brydon, B.A. Darroch, M.H. Entz, and A.M. Johnston. 1990. Environment and genotype influence on grain protein concentration of wheat and rye. Agron. J. 82:666-674.

Fundación Chile. 2005. Una nueva visión para el sector triguero en Chile. 100 p. Fundación Chile, Santiago, Chile.

Gauer, L.E., C.A. Grant, D.T. Gehl, and L.D. Bailey. 1992. Effects of nitrogen fertilization on grain protein content, nitrogen uptake, and nitrogen use efficiency of six spring wheat (Triticum aestivum L.) cultivars, in relation to estimated moisture supply. Can. J. Plant Sci. 72:235-241.

Instituto Nacional de Normalización. 2000. Norma Chilena. Nch 1237-2000. Trigo harinero-Requisitos. 16 p. Instituto Nacional de Normalización, Santiago, Chile.

Jobet, C., y C. Hewstone. 2003. Kumpa-INIA: nueva variedad de trigo invernal para el sur de Chile. Agric. Téc. (Chile) 63:81-86.

López-Bellido, L., R.J. López-Bellido, and F.J. LópezBellido. 2006. Fertilizer nitrogen efficiency in durum wheat under rainfed Mediterraneam conditions: Effect of split application. Agron. J. 98:55-62.

Macdonald, A.J., P.R. Poulton, E.A. Stockdale, D.S. Powlson, and D.S. Jenkinson. 2002. The fate of residual N-15-labelled fertilizer in arable soils: Its availability to subsequent crops and retention in soil. Plant Soil 246:123-137.

Mellado, M. 1992. Eficiencia de dos fertilizantes nitrogenados aplicados en diferentes estados fenológicos en una variedad de trigo invernal (Triticum aestivum L.) Agric. Téc. (Chile) 53:251-257.

Moll, R.H., E.J. Kamprath, and W.A. Jackson. 1982. Analysis and interpretation of factors which contribute to efficiency of nitrogen utilization. Agron. J. 74:562564.

Ortiz-Monasterio, J.I., K.D. Sayre, S. Rajaram, and M. McMahon. 1997. Genetic progress in wheat yield and nitrogen use efficiency under four nitrogen rates. Crop Sci. 37:898-904.
ODEPA. 2008a. Evolución reciente de los precios de los fertilizantes. 34 p. Ministerio de Agricultura, Oficina de Estudios y Políticas Agrarias (ODEPA), Santiago, Chile.

ODEPA. 2008b. Estadísticas agropecuarias. Cultivos anuales, frutales y hortalizas. Ministerio de Agricultura, Oficina de Estudios y Políticas Agrarias (ODEPA), Santiago, Chile. Available at http://www. odepa.minagri.gob.cl (accessed 16 December 2008).

Parodi, P. 2003. Mayor eficiencia en el uso del nitrógeno puede aumentar la rentabilidad del trigo y hacerlo más amigable hacia el ambiente. p. 275-283. In Kohli, M.M., M. Díaz, y M. Castro (eds.) Seminario Internacional Estrategias y Metodologías Utilizadas en el Mejoramiento de Trigo, La Estanzuela, Uruguay. 8-11 de octubre de 2001. CIMMYT-INIA, Colonia, Uruguay.

Raun, W.R., and G.V. Johnson. 1999. Improving nitrogen use efficiency for cereal production. Agron. J. 91:357363.

Raun, W.R., J.B. Solie, G.V. Johnson, M.L.Stone, R.W. Mullen, K.W. Freeman, W.E. Thomason, and E.V. Lukina. 2002. Improving nitrogen use efficiency in cereal grain production with optical sensing and variable rate application. Agron. J. 94:815-820.

Rebolledo, H. 1999. Estimación de modelos de regresión a experimentos de fertilización y obtención de dosis óptimas económicas de insumos agrícolas. $55 \mathrm{p}$. Universidad Autónoma Chapingo, Departamento de Suelos, Chapingo, México.

Rodríguez, J. 1991. Manual de fertilización. 362 p. Colección en Agricultura. Pontificia Universidad Católica de Chile, Facultad de Agronomía. Alfabeta Impresores, Santiago, Chile.

Sadzawka, A., M.A. Carrasco, R. Grez, M.L. Mora, H. Flores, y A. Reaman. 2006. Métodos de análisis recomendados para los suelos de Chile. Revisión 2006. Serie Actas INIA No 34. 164 p. Instituto de Investigaciones Agropecuarias, Centro Regional de Investigación La Platina, Santiago, Chile.

SAS Institute. 1990. SAS/STAT user's guide: statistic. Versión 6. $4^{\text {th }}$ ed. SAS Institute, Cary, North Carolina, USA.

Semenov, M.A., P.D. Jamieson, and P. Martre. 2007. Deconvoluting nitrogen use efficiency in wheat: A simulation study. Eur. J. Agron. 26:283-294.

Stone, P., and R. Savin. 1999. Grain quality and its physiological determinants. p. 85-120. In Satorre, E., and G. Slafer (eds.) Wheat: Ecology and physiology of yield determination. Food Products Press, New York, USA. 
Suárez, D. 1994. Uso de cales y fertilizantes en praderas de la zona sur. p. 39-65. In L. Latrille (ed.) Producción Animal Serie B No 18. Universidad Austral de Chile, Instituto de Producción Animal, Valdivia, Chile.

Tilman, D., K.G. Cassman, P.A. Matson, R. Naylor, and S. Polasky. 2002. Agricultural sustainability and intensive production practices. Nature 418:671-677.

Tran, T.S., and G. Tremblay. 2000. Recovery of $15 \mathrm{~N}$-labeled fertilizer by spring bread wheat at different $\mathrm{N}$ rates and application times. Can. J. Soil Sci. 80:533-539.
Urquiaga, S. 2000. Eficiencia de la fertilización nitrogenada en los principales cultivos anuales. p. 31-49. In Urquiaga, S., y F. Zapata (eds.) Manejo eficiente de la fertilización nitrogenada de cultivos anuales en América Latina y el Caribe. Rio de Janeiro, EMBRAPA Agrobiología, Seropédica, Rio de Janeiro, Brasil.

Volke, H.V. 1982. Optimización de insumos de la producción en la agricultura. 61 p. Colegio de Postgraduados, México D.F., México.

Zadoks, J.C., T.T. Chang, and C.F. Zonzak. 1974. A decimal code for the growth stages of cereals. Weed Res. 14:415-421. 